\title{
FASHION REVOLUTION AS PROMOTER OF SOCIAL INNOVATION AND SUSTAINABILITY IN FASHION
}

\author{
Solange FERNANDES ${ }^{*}$, Isabela Dias HONÓRIO², Alexandra CRUCHINHO ${ }^{2}$, Maria José MADEIRA ${ }^{1}$ José LUCAS ${ }^{1}$ \\ ${ }^{1}$ University of Beira Interior, Covilhã-Portugal \\ ${ }^{2}$ State University of Londrina, Londrina, PR-Brasil \\ ${ }^{3}$ Polytechnic Institute of Castelo Branco-Portugal
}

Received: 17.01.2020

Accepted: 02.03.2020

https://doi.org/10.24264/Ifj.20.1.6

\section{FASHION REVOLUTION AS PROMOTER OF SOCIAL INNOVATION AND SUSTAINABILITY IN FASHION}

ABSTRACT. Fashion Revolution is a global collaborative movement that seeks to increase transparency across industry's production chain and counteract misunderstanding. The movement calls university students around the world to become ambassadors and to become activist designers. Also, students, teachers, businesses, professionals and the community to discuss consumption, sustainable development of fashion and getting millions of people demanding fashion transparency, through brand questioning: \#whomademyclothes. This article aims a fashion week revolution, promoting knowledge as social innovation for sustainability when launching a concept as a business value proposition. Authors present a CANVAS and Pestle business model to support future implementation of this conceptual idea. One concludes that design of product-service systems, allied to fashion revolution movement, helps foster social innovation, stimulates circularity, induces behavioural consumption changes, promotes dematerialization of energy consumption, redistribution of idle products, available resources management with social and environmental benefits, through online platform and app.

KEY WORDS: activism design, systems design, social innovation, 2P2 platform

MIŞCAREA FASHION REVOLUTION CA PROMOTOR AL INOVĂRII SOCIALE ŞI SUSTENABILITĂTII ÎN MODĂ

REZUMAT. Fashion Revolution este o mişcare de colaborare globală care urmăreşte să crească transparenţa în lanţul de producţie al industriei şi să contracareze neînţelegerile. Mişcarea îndeamnă studenţii universitari din întreaga lume să devină ambasadori şi designeri activişti. Se adresează, de asemenea, studenţilor, profesorilor, întreprinderilor, profesioniştilor şi comunităţii, în vederea purtării unor discuţii despre consum, dezvoltarea durabilă a modei şi determinarea a milioane de oameni care să solicite transparenţa în modă, prin punerea mărcii sub semnul întrebării: \#whomademyclothes. Acest articol are ca scop o revoluţie a săptămânii modei, promovând cunoaşterea ca inovare socială pentru sustenabilitate la lansarea unui concept ca propunere de afaceri. Autorii prezintă un model de afaceri CANVAS şi Pestle pentru a sprijini implementarea viitoare a acestei idei conceptuale. Se concluzionează că proiectarea sistemelor de servicii-produse, aliată mişcării Fashion Revolution, încurajează inovarea socială, stimulează circularitatea, induce schimbări ale comportamentului de consum, promovează dematerializarea consumului de energie, redistribuirea produselor inactive, gestionarea resurselor disponibile cu beneficii sociale şi de mediu, prin intermediul unei platforme online şi a unei aplicaţii.

CUVINTE CHEIE: design activist, designul sistemelor, inovare socială, platforma 2P2

LE MOUVEMENT FASHION REVOLUTION EN TANT QUE PROMOTEUR DE L'INNOVATION SOCIALE ET DE LA DURABILITÉ DANS LA MODE RÉSUMÉ. Fashion Revolution est un mouvement collaboratif mondial qui vise à accroître la transparence à travers la chaîne de production de l'industrie et à lutter contre les malentendus. Le mouvement appelle les étudiants universitaires du monde entier à devenir des ambassadeurs et à devenir des designers activistes. Il s'adresse également aux étudiants, aux enseignants, aux entreprises, aux professionnels et à la communauté, pour discuter de la consommation, du développement durable de la mode et amener des millions de personnes à exiger la transparence de la mode, à travers le questionnement de la marque: \#whomademyclothes. Cet article vise une révolution de la semaine de la mode, en promouvant la connaissance comme innovation sociale pour la durabilité lors du lancement d'un concept en tant que proposition de valeur commerciale. Les auteurs présentent un modèle commercial CANVAS et Pestle pour soutenir la future mise en œuvre de cette idée conceptuelle. On conclut que la conception de systèmes de produits-services, alliée au mouvement de Fashion Revolution, favorise l'innovation sociale, stimule la circularité, induit des changements du comportement de consommation, favorise la dématérialisation de la consommation d'énergie, la redistribution des produits inactifs, la gestion des ressources disponibles avec des avantages sociaux et environnementaux, via une plateforme en ligne et une application.

MOTS CLÉS: design activiste, conception de systèmes, innovation sociale, plateforme 2P2

\footnotetext{
* Correspondence to: Solange FERNANDES, University of Beira Interior, FibEnTech R\&D Unit, R. Marquês D'Ávila e Bolama, 6201-001, Covilhã, Portugal, embaixadorafrubi@gmail.com
} 


\section{INTRODUCTION}

The fashion industry is considered the second most polluting in the world. The textile, clothing and footwear system (fashion industry) operates in a linear fashion: large amounts of nonrenewable resources are extracted to produce clothing and shoes that are used for a short time and are subsequently dumped into landfills, incinerated or sent to underdeveloped countries. These problems worsened even further from the 2000s, when fast fashion chains emerged, and production and consumption increased, thereby increasing social and environmental problems [2].

The international activist movement Fashion Revolution [3] was created following the collapse of a garment industry in Dhaka, Bangladesh, on April 24, 2013, in which 1,138 people died and more than 2,500 were injured. Such a tragedy touched a group of people in the UK who decided to found the collaborative Fashion Revolution movement, Carry Somers was the founder and director of global operations. In 2014 in the first edition, the movement was organized in several countries of the world and grew every year.

Fashion Revolution aims to make the production chain more transparent to the eyes of consumers and with that, ensure that a tragedy like the one that happened in Rana Plaza never happens again. According to the organizers the simple question "Who made my clothes?" contributes greatly to a change in this process.

Bringing the protagonists of the industry to the fore, Fashion Revolution aims to change the narrative around clothing, inspiring positive and permanent changes in the fashion industry.

The death of 1,138 people on one terrible day cannot be forgotten. It is imperative to demand changes that prevent such new accidents, wherever they may be. On April 24 of every year, Fashion Revolution mobilizes the entire fashion chain to question the true cost of fashion, and show to the world that changes are possible in the industry segment [3].

The lack of knowledge of the consumers about the production system, the use of natural resources and the exploitation of the labour contributes to the economy of the discard and to the global warming and social degradation [4].

Fashion Revolution, headquartered in the United Kingdom, is a community-based company comprised of nine people in global coordination, from various fields such as politics, communication, branding and education. They work closely with the Global Advisory Committee to plan and implement the Fashion Revolution campaign each year [3].

Members are responsible for organizing and managing the primary groups and overseeing Fashion Revolution globally. They work on communication, policy and strategy and fundraising for events.

The Global Fashion Revolution coordination is also responsible for the governance of the movement in each country, through regional coordinators. Currently, there are over one hundred countries that are part of the Fashion Revolution movement.

Fashion Revolution country coordinators (CCs), as is the case of Salomé Areias in Portugal, work voluntarily assuming the responsibilities of organizing the Fashion Revolution event in their respective countries. Its main tasks are: facilitating and distributing Fashion Revolution campaign materials; defining communication policy and strategy, in accordance with global guidelines; compiling and presenting annual reports on its impact and evaluatng the progress of Fashion Revolution in the country [3].

\section{EDUCATIONAL ACADEMIC FASHION REVOLUTION}

The Fashion Revolution movement invites university students to become Fashion Revolution ambassadors at their universities, organizing events and achievements there. Between March 29 and April 1, 2017, the first edition of the event was held at the University of Beira Interior, the first Portuguese university to join the movement. The ambassador and organizers of the event Fashion Revolution Week at the University of Beira Interior, had the collaboration and participation of the course directors, professors and graduation, master's and doctorate students in Fashion Design [5].

The objective was to raise awareness among consumers, designers, industry, artisans about the true cost of fashion, both social, environmental and economic; create relationships with universities, fashion design courses, companies and encourage production, 
consumption and circular distribution. Besides, question who made my clothes? [5].

With this, it is expected to sensitize the participants of the event, both regarding social and environmental issues of the fashion industry, in the expectation that they will adhere to the slow fashion, the circular fashion and the change of attitude towards clothing. The first edition was attended by national or international brands that spoke about sustainability in fashion. Brand Natural Cotton Color [6], spoke of the coloured cotton of Paraíba, Brand Away to Mars [7], talked about the creation process open to all. Lala Deheinzelin [8], UNO consultant, spoke on 4D: New and savings to activate the transition. Thomas Echkschmidt [9] talked about Conscious Capitalism, among other important speakers [5].

In the edition of Fashion Revolution at the University of Beira Interior (FRUBI) in 2018, we believed that in order to achieve sustainability in fashion we need to promote a new way of life through social innovation that involves teachers, students, companies, professionals and the local community in the process to accelerate the transition of the circular economy. Thus, the FRUBI of 2018 is divided into three large panels [5]:

- Inner Wellness - Where the sustainable lifestyle is portrayed, from healthy eating habits avoiding the eating disorders driven by the fashion industry, to the separation and recycling of the garbage generated in the dayto-day;

- Exterior Wellness - Panel based on aesthetics, beauty care and styling, interconnecting internationally renowned cosmetic brands and regional products thought of female empowerment;

- Circular Fashion - After the analysis of consumption and identity established in previous days, the last day focuses on finding established brands in the market that work for a more circular, dynamic, creative and above all transparent fashion industry [5].

In addition, a competition was held to raise awareness of the academic and general community for the development of sustainable fashion, driven by innovation, design and creativity, to stimulate the creative and enterprising capacity of the competitors, as well as, to spread to the community the guidelines of the development of sustainable fashion products. One of the parts of the coordinator must comply with the guidelines of one of the following sustainability concepts:

- The concept of upcycling is simple: it consists of creating new parts from the reuse of other pieces of clothing or leftovers, extending the product life cycle;

- Zero Waste: The "zero waste" design process offers a cleaner production alternative, aimed at minimizing waste already in the design and modelling phases, providing a new approach to product development, making production cleaner and reducing its environmental impacts, aiming at the sustainable concept of slow fashion;

- Modular/Multifunctional Clothing: Modular, multifunctional or convertible clothing consists of dresses and blouses with straps that can be configured in various ways or depending on the modelling, transforming the piece into a skirt, scarf, cape, bag, blouse and dress.

The event ended with the presentation of a parade with about 400 people [5].

The Fashion Revolution Week event at the University of Beira Interior - Bachelor, Master's degree in Fashion Design is a pioneering and unique opportunity to explore, in the interaction between students and community, the many issues of the fashion industry such as: workers' rights, transparency in the production chain, global citizenship, sustainable development and ethical business practices [5]

Together people will question: why a fashion revolution? Who makes our clothes? Where are they made? What is the salary and working conditions? What are the environmental consequences?

From 2015, to 2018 the great differential of 
this Movement is the direct interaction with the educational sector of the fashion area, offering material resources to support the participation of the students and the community.

The major challenge of sustainable development is social innovation, which requires a well-informed, participatory and collaborative society that better integrates technical-scientific knowledge for environmental, social and economic sustainability [10].

By connecting design mode courses, these movements also stimulate principals, faculty, and students to rethink the practice of design, designing activism as a tool that can drive transformation throughout the fashion system.

The fashion industry is a global industry with enormous social and environmental impact. The university has a key role in raising awareness of its Fashion Design students and future fashion industry designer. Fashion is not just glamour. It is life and work. Giving students the awareness and the need to reflect on all this with a view to a new model of creating and producing clothes, this being our contribution to sustainability.

Table 1: Sustainable Fashion organizations (In this table are shown only a few of them). For more information visit https://www.fashionrevolution.org/key-organizations and key-organisations at site https://www.fashionrevolution.org [3]

\begin{tabular}{|c|c|c|c|c|}
\hline $\begin{array}{c}\text { Sustainable Fashion } \\
\text { Centre }\end{array}$ & $\begin{array}{l}\text { Clean Clothes } \\
\text { Campaign }\end{array}$ & $\begin{array}{l}\text { Ellen MacArthur } \\
\text { Foundation [11] }\end{array}$ & Fairtrade Foundation & Textile Exchange \\
\hline $\begin{array}{l}\text { Sustainable Fashion } \\
\text { Centre is a research } \\
\text { institute committed } \\
\text { to exploring ways to } \\
\text { use fashion to drive } \\
\text { change through } \\
\text { research and } \\
\text { collaboration be- } \\
\text { tween education and } \\
\text { industry. }\end{array}$ & $\begin{array}{l}\text { The Clean Clothes } \\
\text { Campaign is a global } \\
\text { alliance dedicated } \\
\text { to improving } \\
\text { working conditions } \\
\text { and em-powering } \\
\text { workers in the } \\
\text { global clothing } \\
\text { and sportswear in- } \\
\text { dustries. }\end{array}$ & $\begin{array}{l}\text { The Environmental } \\
\text { Justice Foundation is } \\
\text { working to secure a } \\
\text { world where habitats } \\
\text { and natural environ- } \\
\text { ments can sustain } \\
\text { and be sustained by } \\
\text { the communities that } \\
\text { depend on them for } \\
\text { their basic needs and } \\
\text { livelihoods. }\end{array}$ & $\begin{array}{l}\text { The Fairtrade Foun- } \\
\text { dation's mission is to } \\
\text { connect farmers and } \\
\text { disadvantaged wor- } \\
\text { kers with consumers, } \\
\text { promote fairer trade } \\
\text { conditions and em- } \\
\text { power farmers and } \\
\text { workers to fight } \\
\text { poverty. }\end{array}$ & $\begin{array}{l}\text { Textile Exchange is } \\
\text { a global non-profit } \\
\text { or-ganization that } \\
\text { works to promote the } \\
\text { trans-formation of the } \\
\text { in-dustry into sustain- } \\
\text { able fibres, integrity } \\
\text { and responsible } \\
\text { standards and supply } \\
\text { networks. }\end{array}$ \\
\hline
\end{tabular}

It is growing both by consumers and the brands that have come to answer the questioning about the origin of their productions. A differential of this Movement is the direct interaction with the educational sector, offering material resources to support student participation.

To transform the world, Fashion Revolution believes in the power to work in collaboration with other activist movements.

The way fashion revolution is working and uniting collaborative thinking for the transformation of the garment industry is in the social issues faced by the environmental workers.

For Manzini [10] cultural activists, grassroots organizations and design activities are converging on a variety of initiatives whose purpose is not to provide immediate solutions to problems, but to arouse interest in these scenarios and to show, in general and in a paradoxical or provocative way that exist different ways of looking at them and solving them. Social innovation in design may be one of them because of the natural need or desire to design supported by digital tools and new social networks. This is the case of the fashion revolution platform with guidelines, blog and materials available for downloads. And it works collaboratively in more than 100 countries. The country coordinators always give support on the site during Fashion Revolution week. The movement encourages, do it yourself, upcycling, swap market production, and conscious consumption of fashionable product with value together for all. 


\begin{tabular}{|c|c|c|c|}
\hline FACTORS & ATUAL (consollidated) & FUTURE (emergent) & INSIGHTS LIST \\
\hline $\begin{array}{l}\text { POLITICAL } \\
\text { Regulations } \\
\text { Regional Regimes and Taxation } \\
\text { Government Grants Financing \& } \\
\text { Fundings }\end{array}$ & $\begin{array}{l}\text { Universities internal policies; } \\
\text { Design/platform maintenance fees; } \\
\text { Municipal, State Incentives Incubators } \\
\text { /Investors Crowdfound; }\end{array}$ & $\begin{array}{l}\text { Prevent or hinder the implementation of the } \\
\text { model; } \\
\text { High competition, great app offer, strong } \\
\text { competitive differential; }\end{array}$ & $\begin{array}{l}\text { Possibility to use other } \\
\text { infrastructures, including digital } \\
\text { (app); } \\
\text { Partners, take the project to startups } \\
\text { fairs; }\end{array}$ \\
\hline $\begin{array}{l}\text { ECONOMIC } \\
\text { Cost of labor } \\
\text { Economic scenario } \\
\text { Demand for raw materials }\end{array}$ & $\begin{array}{l}\text { Maintenance of the platform; } \\
\text { Increasing need and awareness of } \\
\text { people in saving; }\end{array}$ & $\begin{array}{l}\text { Make updates on the platform / service } \\
\text { users; } \\
\text { People will look for other ways to save } \\
\text { money; }\end{array}$ & $\begin{array}{l}\text { Outsourced or personal encountered } \\
\text { or partnered with students with any } \\
\text { advantage offered; } \\
\text { Use economics as a marketing call to } \\
\text { win over people who are not yet } \\
\text { into the collaborative lifestyle; }\end{array}$ \\
\hline $\begin{array}{l}\text { SOCIAL } \\
\text { Changes in expectations } \\
\text { Specific pressure and interest } \\
\text { groups } \\
\text { Cultural changes } \\
\text { Role of media } \\
\text { Social responsibility }\end{array}$ & $\begin{array}{l}\text { Circular Economy and collaborative } \\
\text { support groups; } \\
\text { Fashion Revolution Movement pressing } \\
\text { fast fashion companies and raising the } \\
\text { awareness of the population } \\
\text { (alternative media) about the } \\
\text { economic, social and environmental } \\
\text { impacts; } \\
\text { International Learning Network of } \\
\text { networks on Sustainability (LENS); }\end{array}$ & $\begin{array}{l}\text { Universities adhere to a teaching with more } \\
\text { application of the circular and collaborative } \\
\text { economy; } \\
\text { Fashion Revolution Movement in expansion } \\
\text { which will impact more and more the } \\
\text { consumption habits of people; } \\
\text { International Learning Network of networks } \\
\text { on Sustainability; }\end{array}$ & $\begin{array}{l}\text { Actions with students of fashion } \\
\text { design to encourage the application } \\
\text { of circular economy in projects; } \\
\text { To count on the support / } \\
\text { partnership of the Fashion Revolution } \\
\text { Movement and other pressure } \\
\text { groups to actions, publicize and } \\
\text { maintain the system; } \\
\text { Massive presence in social media; } \\
\text { LENS; }\end{array}$ \\
\hline $\begin{array}{l}\text { TECHNOLOGIC } \\
\text { New technologies } \\
\text { Effects of internet } \\
\text { P2P platforms } \\
\text { Need for infrastructures } \\
\text { Availability to adopt innovations }\end{array}$ & $\begin{array}{l}\text { Impact of the internet on the } \\
\text { organization of people; } \\
\text { Strong positioning of facilitating } \\
\text { applications / platforms; } \\
\text { Existing faculty infrastructure; } \\
\text { Young audience at university } \\
\text { (Millenius) with ease of adopting } \\
\text { novelties; }\end{array}$ & $\begin{array}{l}\text { Collaborative economy on the rise which will } \\
\text { redefine people's lifestyles; } \\
\text { Need to adapt existing infrastructure and a } \\
\text { lot of bureaucracy to be feasible to } \\
\text { implement; }\end{array}$ & $\begin{array}{l}\text { Use the internet to publicize the } \\
\text { system; } \\
\text { Create an online platform } \mathrm{p} 2 \mathrm{p} ; \\
\text { Use online platforms to reach more } \\
\text { people and avoid the need for } \\
\text { physical and bureaucratic } \\
\text { infrastructure; } \\
\text { Strategies to initially reach young } \\
\text { people who are more willing to } \\
\text { adopt novelties; }\end{array}$ \\
\hline $\begin{array}{l}\text { LEGAL } \\
\text { Guidelines } \\
\text { Variation in laws by country, state } \\
\text { or region }\end{array}$ & $\begin{array}{l}\text { PERSU } 2020 \text { (Strategic Plan for Urban } \\
\text { Waste); }\end{array}$ & & \\
\hline $\begin{array}{l}\text { ENVIRONMENTAL } \\
\text { Carbon footprint } \\
\text { Emission reduction } \\
\text { Waste Disposal Regulations } \\
\text { Social pressure for social } \\
\text { responsibility }\end{array}$ & $\begin{array}{l}\text { Agendas for compliance with } \\
\text { municipal and regional goals; } \\
\text { Stronger pressure groups; }\end{array}$ & $\begin{array}{l}\text { Agendas delayed; } \\
\text { Increasing and higher visibility charges; }\end{array}$ & $\begin{array}{l}\text { Seek support for companies and } \\
\text { agencies that have a late } \\
\text { compliance agenda; } \\
\text { Maximize use and delay the } \\
\text { disposal of parts in nature; } \\
\text { Conscious designers. }\end{array}$ \\
\hline
\end{tabular}

Figure 1. PESTLE analysis. Adapted from Sampaio, 2017 [12]

According to Fuad-Luke [13] design activists make their "moves" create a critical mass. This can significantly impact the transformation of the clothing industry and our consumption habits.

Fashion Revolution is seen as a promoter of the social innovation of Fashion library P2P $U B I$, is in the process of development together with the Informatics Department of UBI.

Manzini [10] states that design for social innovation is service design (to design and develop solution ideas that take into account the quality of the interactions involved) and strategic design (to promote and support partnerships between the different actors involved). It also produces significant social innovations, that is, solutions based on new social forms and new economic models.
Social design deals with all types of social change geared to sustainability: changes that can reduce its environmental impact, regenerate common goods and strengthen the social community. 
The Business Model Canvas

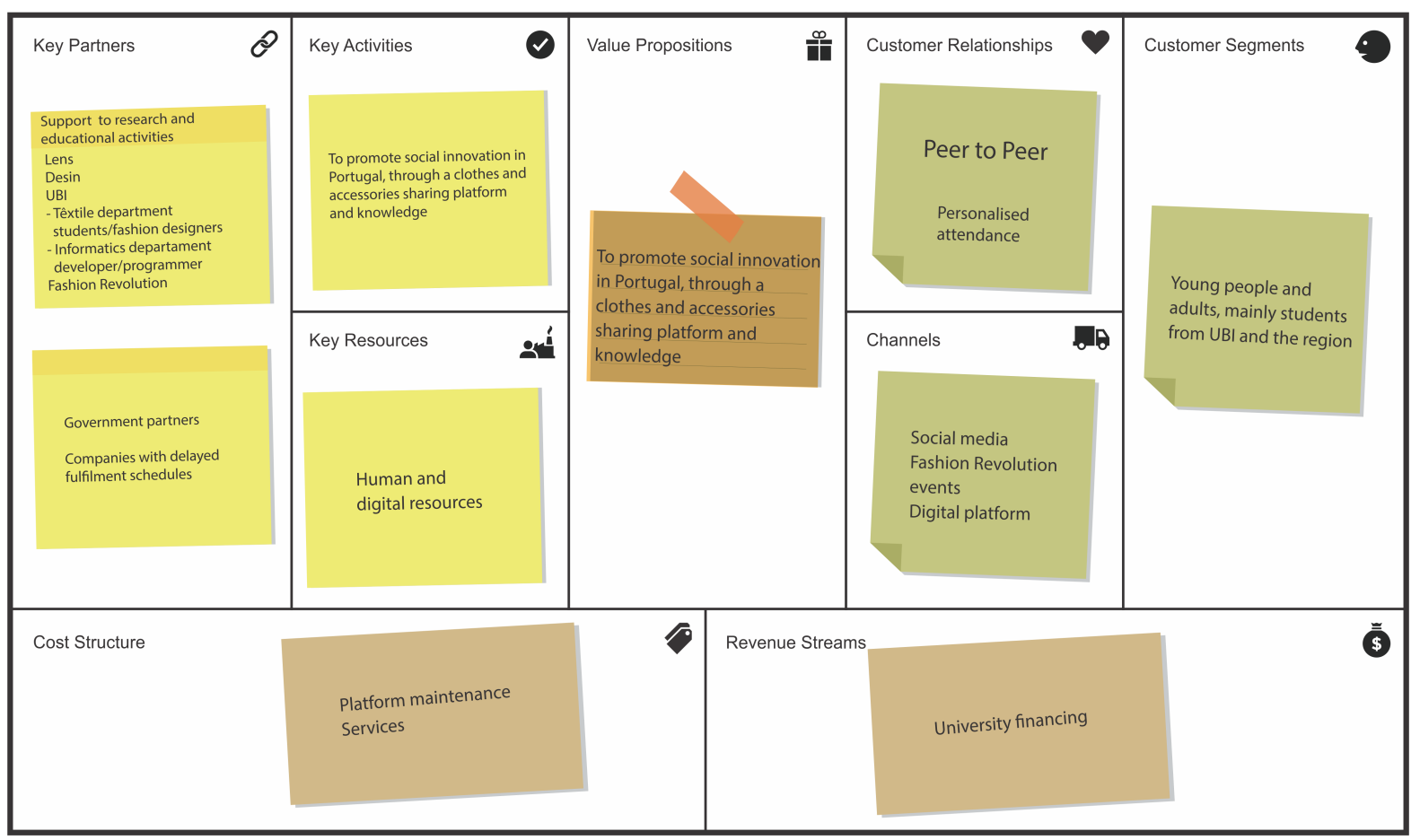

Figure 2. The Business Model Canvas, adapted from Sampaio [12]

\section{FASHION LI BRARY}

\section{CONECTING PEOPLE, CLOTHES AND KNOWLOEDGE}

\section{JOIN US}

Figure 3. Landing page "Home". Adapted from Solange et al. [14] 


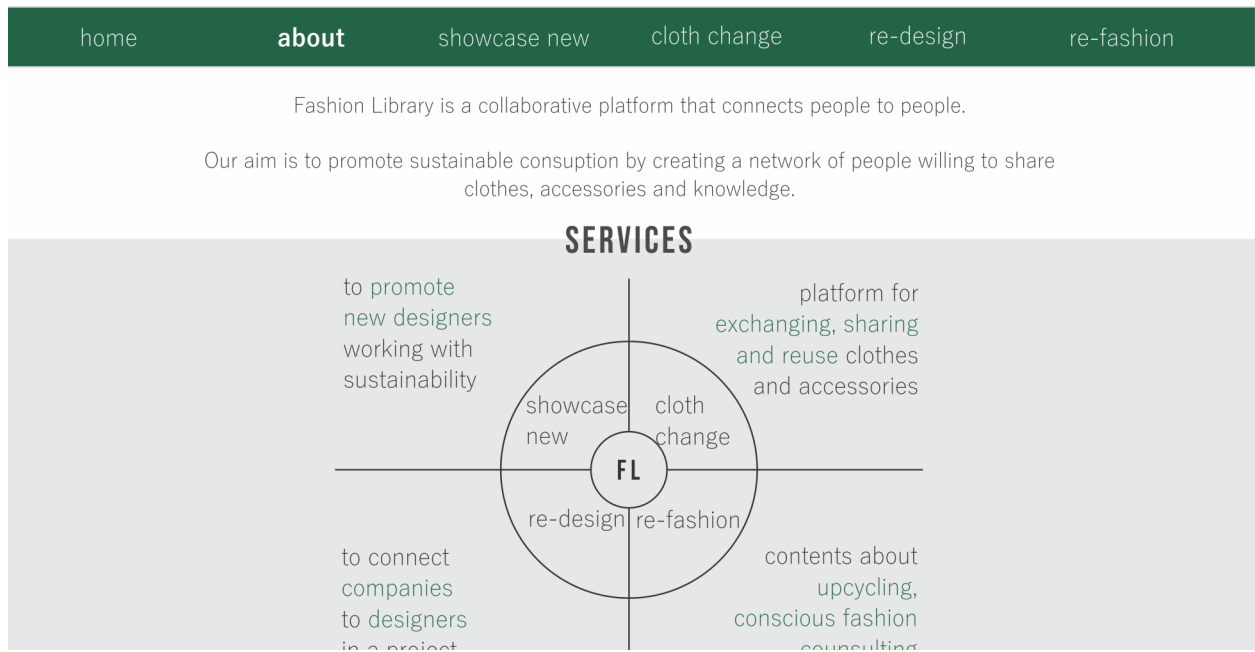

Figure 4. Landing page "About". Adapted from Solange et al. [14]

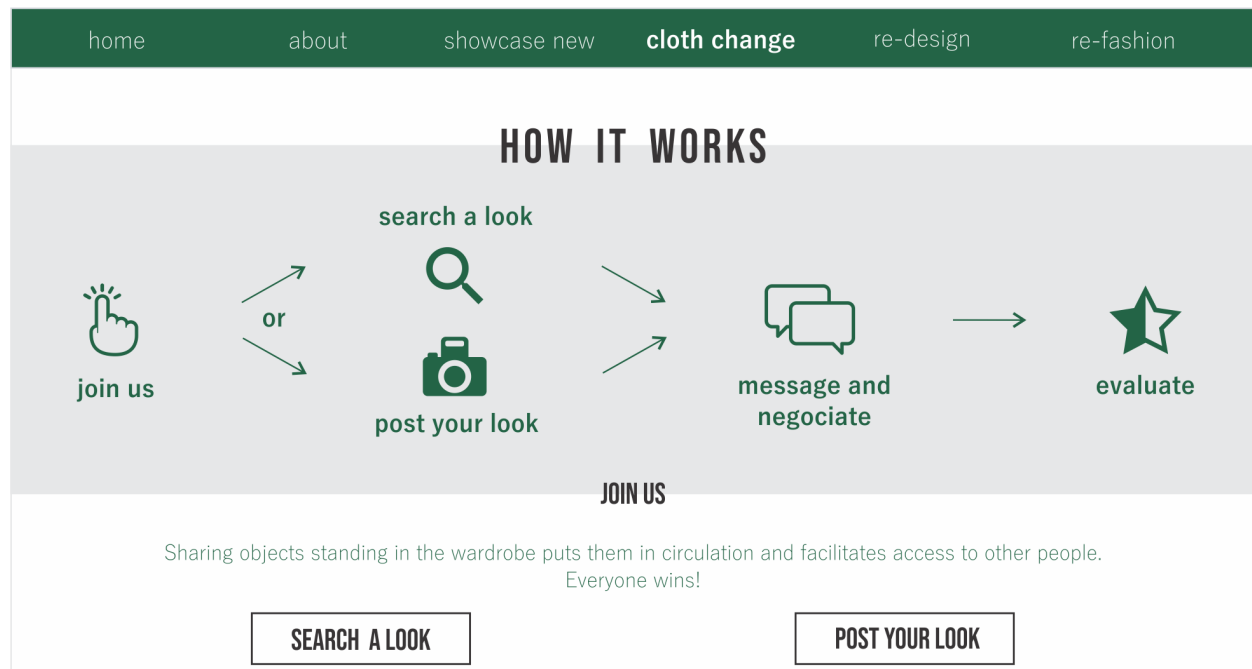

Figure 5. Landing page "Cloth change". Adapted from thenuwardrobe, 2018 [15]

\section{FINAL CONSIDERATIONS}

Initially, the perceived obstacles were the behaviour of Portuguese consumers, who are not accustomed to access business models that replace the property. There is a lack of awareness and mobilization of citizens and economic agents.

Its implementation is proposed in Covilhã, Portugal, with the provision of eco-efficient, collaborative and sustainable services in fashion products, which can be replicated in its entirety, or by parts, in other places and contexts, adopting, for this, modularity as an adaptive resource. Adoption of the system will depend heavily on the culture to which it is embedded.

It will be an online P2P platform to connect source and demand promoting access to clothing, without the need to buy, will thus help change the perception of disposable article apparel to a reusable product. The cleaning will be done by the home user who lends the clothes. "Increasing the number of times clothes are worn may be the most powerful way to capture value, reduce resource pressure and reduce negative impacts" [13].

Accelerating sustainable development requires a paradigm shift in terms of the productive process in order to migrate from a linear to a circular economy: it is about changing habits, the mentalities and methods rooted in society.

According to 2030 agenda the future of research and innovation for the Circular Economy in Portugal depends on a collective 
approach, along with the collaborative economy, involving the Academy in the first place, with multidisciplinary models of interaction in civil society [16].

This project has as target audience the generation Millennials, also known as generation or the "generation Uber" or "Airbnb" that use the collaborative economy.

Rifkin [17] has published a book called "The Age of Access", in which presented the future transitions of economic activities based on access to goods and services through the shared use. The shared consumption will cause a real revolution of behaviours for the sake of sustainability, pointing to the replacement of products for services. The shared practices are ways of optimizing the lifetime of the products, reducing the need for new products, leading to less environmental impact. This is to say that it reduces the amount of discarded products which can reduce up to $50 \%$ the environmental impact as compared with the single use. And the footwear and accessories industry is also discussing this topic, preparing new solutions and approaches [18].

\section{REFERENCES}

1. Vezzoli, C., Design de sistema para a Sustentabilidade: teoria, métodos e ferramentas para o design sustentável de "sistemas de satisfação", Salvador, EDUFA, 2010.

2. Fletcher, K., Grose, L., Moda \& Sustentabilidade. Design para mudança, São Paulo: SENAC, 2011.

3. Fashion Revolution, available at: https:// www.fashionrevolution.org/, accessed 12 September 2018.

4. Gansky, L., Mesh: Por que o Futuro dos Negócios é Compartilhar, Rio de Janeiro: Atla Books, 2011.

5. Fashion Revolution ubi Conference Proceedings, available at: https://www. fashionrevolutionubi.com/, accessed 12 September 2018.

6. Natural Cotton Color, available at: http:// www.naturalcottoncolor.com.br, accessed 12 September 2018.

7. Away to Mars, https://www.awaytomars.com.

8. Lala Deheinzelin, available at: http:// laladeheinzelin.com.br/, accessed 12 September 2018.
9. Echkschmidt, T., O capitalismo pode ser consciente?, 10 May 2018, available at: https://www.inovabs.com.br/paulista/blog/ capitalismo-consciente-o-capitalismo-podeser-consciente-por-thomas-eckschmidt.

10. Manzini, E., Vezzoli, C., O Desenvolvimento de Produtos Sustentáveis. Os requisitos ambientais dos produtos industriais, São Paulo: Editora da Universidade de São Paulo, 2005 (10 Ed. 2001), accessed 12 September 2018.

11. Ellen MacArthur Foundation: A New Textile Economy Full Report-Updated, Homepage, available at: https://www. ellenmacarthurfoundation.org/assets/ downloads/publications/A-New-TextilesEconomy_Full-Report_Updated_1-12-17.pdf, accessed 12 September 2018.

12. Sampaio, P.C., Flows Modelo Integradode P\&D Em Resíduos Sólidos, Tese De Doutoramento Em Design, Faulisboa, 2017.

13. Fuad-Luke, A., Design Activism: beautiful strangeness for a sustainable world, London: Earthscan, 2009.

14. Solange, F., Lucas, J., Madeira, M.J., Cruchinho, A., Collaborative Sustainable Business Model-Fashion Library, 24th APDR Congress "Intellectual Capital and Regional Development: New landscapes and challenges for space planning", ISBN 978-9898780-05-82017, July 6-7, 2017, University of Beira Interior, Covilhã, Portugal, p. 984

15. thenuwardrobe, available at: https:// www.thenuwardrobe.com/, accessed 12 September 2018.

16. Fundação Para A Ciência E A Tecnologia, Agenda Temática De Investigação E Inovação Economia Circular, 2018.

17. Rifkin, J., A era do acesso, São Paulo: Makron Books, 2001.

18. Azambuja, P., Marques, A., Broega, A., Sustainability in the Portuguese Fashion Accessory and Footwear Industry (Case Studies), Leather and Footwear Journal, 2019, 19, 1, 41-50, https://doi.org/10.24264/ Ifj.19.1.5.

(C) 2020 by the author(s). Published by INCDTPICPI, Bucharest, RO. This is an open access article distributed under the terms and conditions of the Creative Commons Attribution license (http://creativecommons.org/licenses/by/4.0/). 